\title{
Risk Assessment of Poly Cyclic Aromatic Hydrocarbons in the Holy City of Makkah, Saudi Arabia
}

\author{
Turki M. Habeebullah
}

\begin{abstract}
There is a lack of information on polycyclic aromatic hydrocarbons (PAHs) as environmental pollutants in Saudi Arabia. The current study focuses on the risk assessment of polycyclic aromatic hydrocarbons (PAHs), in the Holy city of Makkah, Saudi Arabia, during Hajj season 1431H. Atmospheric particulate matter was collected using High Volume samplers. Samples of $24 \mathrm{~h}$ were collected at three sampling sites, Al-Shebakah, Al-Aziziah and Mina. PAH compounds were quantified by using GC. The total PAH concentrations $\left(\mathrm{ng} / \mathrm{m}^{3}\right)$ ranged from 103.5 - 195.2 with mean values of 164.67, 137.81 and 132.40 for $T S P, P_{10}, P M_{2.5}$, respectively. The higher percentages of the total carcinogenic compounds were recorded at Al-Shebakah, with a maximum value of $63.5 \%$ in $\mathbf{P M}_{10}$. The carcinogenic PAHs, dibenzo[a]pyrene was found at low concentrations.
\end{abstract}

Index Terms-Polycyclic aromatic hydrocarbons, risk assessment, makkah.

\section{INTRODUCTION}

Polycyclic aromatic hydrocarbons (PAHs) are widely distributed as environmental pollutants and have both anthropogenic and natural sources [1]. PAHs are semi-volatile organic compounds, and present in both gaseous and particulate phases. The partitioning of PAH compounds between the particulate and gaseous phases depends on the atmospheric conditions, the nature of aerosol, the interactions between the compound and the aerosol, and the overall behavior of the compound in the atmosphere [2].

PAHs are generated through the combustion of fossil fuel and biomass. Combustion sources include automobiles, power plants, industries, burning coal and petroleum, and waste incinerators. In urban and industrial areas, atmospheric PAHs are almost entirely anthropogenic in origin and are produced by high-temperature reactions, such as incomplete combustion and pyrolysis of fossil fuels and other organic materials containing carbon and hydrogen [3]. The major sources of PAHs in urban atmosphere are gasoline and diesel vehicle exhausts, tire wear debris, asphalt particles, re-suspended soils, and power plants [3]. Natural emission sources of PAHs include forest fires and volcanoes.

PAHs have been identified to be one of the major toxic air pollutants, and some of their degradation products have been known as carcinogenic, mutagenic, and allergenic agents to human health [1].Many studies have focused on PAHs levels, and distribution in suspended particulate matter [4], wet

Manuscript received December 4, 2012; revised February 8, 2013

Turki M. Habeebullah is with The Custodian of the Two Holy Mosques Institute for Hajj and Umrah Research, Umm Al-Qura University (e-mail: t_habeebullah@yahoo.com). deposition [5], road dust [6] and gas phase [7].

Little attention has been paid to the PAHs compounds in Saudi Arabia. The aim of the present study was to evaluate the concentration levels of $\mathrm{PAH}$ compounds in the atmosphere of Makkah city, identify the possible sources of PAHs based on diagnostic ratios of PAH compounds, and evaluate health risks associated with inhalation of $\mathrm{PAH}$ compounds.

\section{Procedure FOR PAPER SUBMISSION}

\section{A. Description of Sampling Sites}

The Holy City of Makkah (Latitude $1925^{\circ} 21$ North Meridian $4649^{\circ} 39$ ) is at an elevation of $277 \mathrm{~m}$ above the sea level, and $\sim 80 \mathrm{~km}$ inland from the Red Sea. Transportation facilities related to the Hajj or Umrah are the main sources of emissions during the season of Hajj and the month of Ramadhan. . Three measurement locations (Fig. 1) were selected namely: Al-Shebakah, Al-Azizia and Mina, in order to represent different activities and natural factors (Table I).

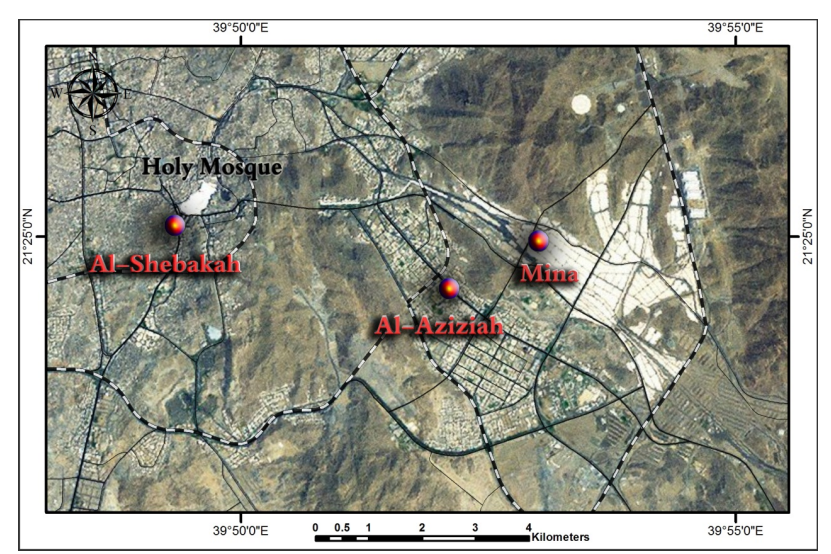

Fig.1. Map of measurment locations.

TABLE I: CHARACTERISTICS OF MEASURMENT LOCATIONS.

\begin{tabular}{c|c|l}
\hline Site. & Area & \multicolumn{1}{c}{ Characterization } \\
\hline 1 & Al-Shebakah, & $\begin{array}{l}\text { Residential area is located at the central of Makkah, } \\
\text { western area of Haram. }\end{array}$ \\
\hline 2 & Al-Aziziah & $\begin{array}{l}\text { Residential area, is located downwind of Haram, } \\
\text { has high traffic density, various types of activities. }\end{array}$ \\
\hline 3 & Mina & $\begin{array}{l}\text { Residential area, is located in the eastern area of } \\
\text { Haram, has high population, and traffic density }\end{array}$ \\
\hline
\end{tabular}

\section{B. Sampling}

The air samples were collected on glass fiber filters (Whatmann GFA), with 99\% collection efficiency [8], using high volume samplers, for 24 hour period, at a height of $3 \mathrm{~m}$ 
above the ground level. Before sampling, the glass fiber filters were impregnated in acetone to remove all organic compounds, and stored in desiccators until sampling [9].

\section{Pahs Analysis and Extraction}

The filters were dried, and reweighed to obtain concentrations of particulate matter, TSP, $\mathrm{PM}_{10}, \mathrm{PM}_{2.5}$. The filters were stored in dark until analyzed [10]. PAHs were extracted with $10 \mathrm{ml}$ of DCM/n-hexane (1:1), fractionated by column chromatography, and eluted with $20 \mathrm{~mL}$ of $\mathrm{n}$-hexane/dichloromethane (1:1, v:v), according to methods previously described[11].

A $2 \mu \mathrm{l}$ of the extract was injected on GC-FID, Model HP

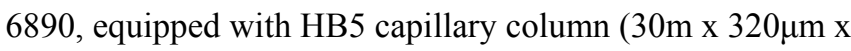
$0.25 \mu \mathrm{m})$. The GC was calibrated with a diluted standard solution of 16 PAH compounds (Supelco, Inc., Bellefonte, PA), including. Naphthalene (NAP), Acenaphthylene (ACY), Acenaphthene (ACE), Phenanthrene (PHE), Fluorine (FLU), Anthracene (ANC), Fluoranthene (FLA), Pyrene (PYR), Benzo(a)anthracene (BaA), Chrysene (CRY), Benzo (b)fluoranthene (BbF), Benzo (k)fluoranthene (BkF), Benzo (a)pyrene (BaP), Dibenzo (a,h)anthracene (DBA), Indeno (1,2,3-c,d)pyrene (IND) and Benzo (ghi) perylene (BgP).

\section{RESULTS AND DISCUSSION}

The concentrations of PAHs at the sampling sites are shown in Table II, and Fig. 2. The total PAH concentrations ranged between 128.72 to $195.2 \mathrm{ng} / \mathrm{m}^{3}$ with a mean value of $164.67 \mathrm{ng} / \mathrm{m}^{3}$ for TSP, 120.13 to $166.48 \mathrm{ng} / \mathrm{m}^{3}$ with mean value of $137.81 \mathrm{ng} / \mathrm{m}^{3}$ for $\mathrm{PM}_{10}$, and 103.5 to $184.95 \mathrm{ng} / \mathrm{m}^{3}$ with a mean value $132.40 \mathrm{ng} / \mathrm{m}^{3}$ for $\mathrm{PM}_{2.5}$. The lowest $\mathrm{PAH}$ was recorded at Al-Azizia (Fig. 2). The total PAH concentrations in Makkah city were between 8 and18 times higher than those detected in London, $17.23 \mathrm{ng} / \mathrm{m}^{3}$ [12], and Hong Kong , $7.42 \mathrm{ng} / \mathrm{m}^{3}$ [13].

PAH compoundswere classified according to the number of aromatic rings into: 2-rings, NAP, 1-MNAP and 2-MNAP; 3-rings, ACY, ACE, FLU, ANT and PHE; 4-rings, FLA, PYR, BAA and CHR; and 5-rings, BBF, BKF, BAP and DBA; 6-ring including BGP and IND, (Table II).The 3-ring PAHs were the most predominant compounds, ranged between $27.4-46.4 \%, 23.3-31.6 \%$ and $28.6-47.8 \%$, for TSP, $\mathrm{PM}_{10}$ and $\mathrm{PM}_{2.5}$, respectively (Fig. 3).

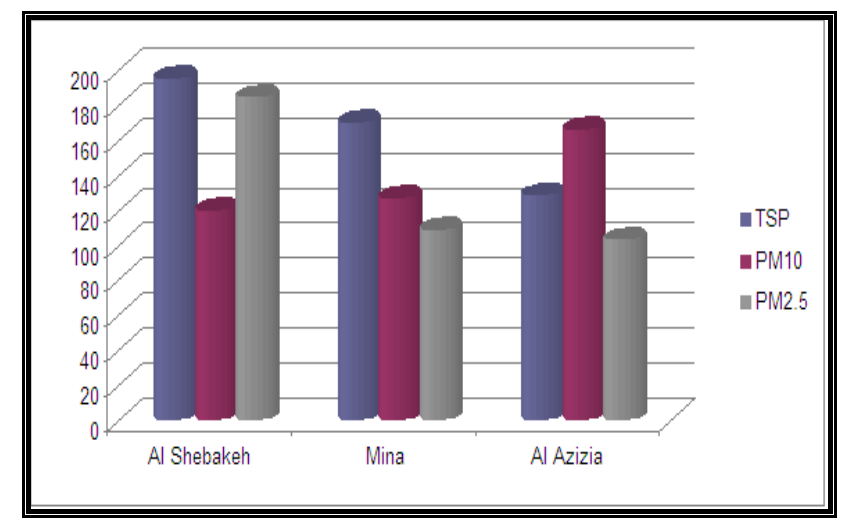

Fig. 2. Total $\sum$ PAHs in different fractions of particulates at measurment locations.

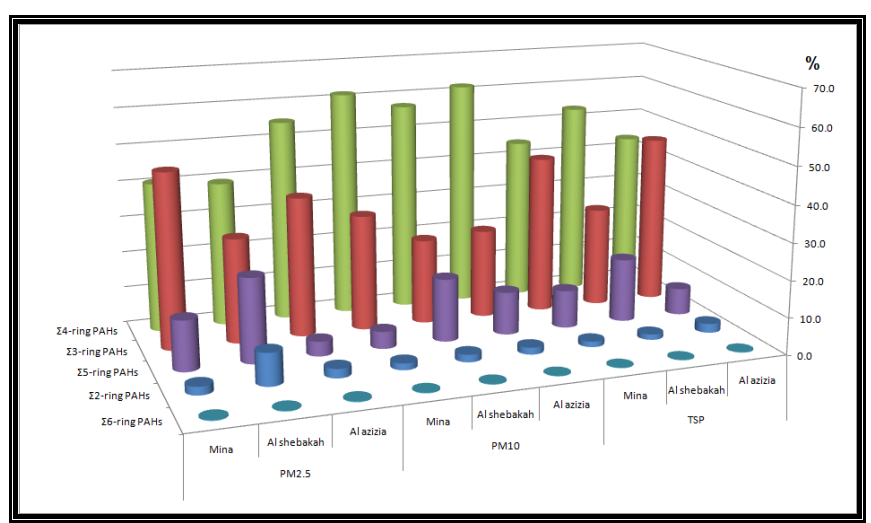

Fig. 3. Percent of $\sum$ PAHs for each ring-type to $\sum$ total-PAHs in different fractions of particulates at measurment locations.

In the present study, the PAHs levels were lower than those found in New Delhi, India [14], and higher than those found in Taichung, Taiwan [15]. The PAHs levels ranged from 6.46 to $31.7 \mathrm{ng} / \mathrm{m}^{3}$ at a residential area, nearby traffic road, and 6.52 to $38.8 \mathrm{ng} / \mathrm{m}^{3}$ nearby commercial and light industrial area, in Hong Kong [16]. All previous studies resulted that vehicular traffic was the major source of PAHs in urban area.

Table III shows the diagnostic ratios of PAHs concentrations. The ratios indicated greater contribution of the traffic sources to the ambient concentrations, in Al-Shebakah. The diagnostic ratios of IND/BGP averaged 5 at the all sampling sites, in all dust fractions, indicating that the main source of PAHs is diesel vehicle. BGP/IND ratios averaged $\sim 0.83$, these ratios displayed high percentage of petrol and diesel engines in all sampling sites. However, $\mathrm{IND} /$ (IND+BGP) ratios averaged $\sim 0.85$ for TSP, $\mathrm{PM}_{10}$ and $\mathrm{PM}_{2.5}$ in all sampling sites. The obtained ratios were close to the oil combustion ratios, 0.36-0.57, reported in China [17]. The calculated ratios of $\mathrm{BAA} /(\mathrm{BAA}+\mathrm{CRY})$ ranged between, 0.6 and 1.0, for TSP, $\mathrm{PM}_{10}$ and $\mathrm{PM}_{2.5}$ in all sampling sites. These findings are similar to ratios which were measured for diesel engines, 0.38-0.64 [4], and industrial areas, 0.23-0.89 [17].

Typical combustion origin PAHs can be indicated by CPAH species (combustible PAHs species; FLT, PYR, BAA, CRY, BBF, BAP, BGP and IND).

The $\mathrm{CPAH} / \Sigma \mathrm{PAH}$ ratios at sampling sites for each $\mathrm{PM}$ fraction are shown in Table IV. The CPAH/ $\Sigma \mathrm{PAH}$ ratios ranged between 0.51 and $0.71,0.66$ and 0.74 , and 0.54 and 0.59 , for TSP, $\mathrm{PM}_{10}$ and $\mathrm{PM}_{2.5}$. These results agree with those found for non-catalyst equipped automobiles and heavy-duty diesel trucks [78].

BAA, BBF, BAP, DBA and IND are probably considered human carcinogens, whereas ACY, ANC, BgP, FLA, PYR and FLU are not classified as promoters of cancer risk [18]. In the current study, the total carcinogenic compounds, BAA, BBF, BAP, DBA and IND, and $\triangle \mathrm{PAH}$ for each PM size-fractionatthe sampling sites are shown in Fig. 4. The higher concentrations for the total carcinogenic compounds were shown in Al-Shebakah for TSP and $\mathrm{PM}_{2.5}$, in Al-Azizia for $\mathrm{PM}_{10}$, as a consequence of high traffic density. 
TABLE II: THE CONCENTRATIONS (NG/M3) OF THE INDIVIDUAL PAH COMPOUNDS AND DIFFERENT CATEGORIES OF PAHS BASED ON AROMATIC RING NUMBER AT MEASURMENT LOCATIONS.

\begin{tabular}{|c|c|c|c|c|c|c|c|c|c|c|}
\hline & \multirow{2}{*}{ Compounds/ Site } & \multicolumn{3}{|c|}{ TSP } & \multicolumn{3}{|c|}{$\mathrm{PM}_{10}$} & \multicolumn{3}{|c|}{$\mathrm{PM}_{2.5}$} \\
\hline & & Al-Azizia & Al-Shebakah & Mina & Al-Azizia & Al-Shebakah & Mina & Al-Azizia & Al-Shebakah & Mina \\
\hline \multirow{4}{*}{ 2-ring } & NAP & 1.463 & 1.032 & 0.87 & 1.683 & 0.852 & 0.768 & 0.8625 & 2.574 & 0.8216 \\
\hline & 1-MNAP & 0.87 & 0.92 & 0.858 & 0.733 & 0.792 & 0.757 & 0.8625 & 0.96 & 0.8217 \\
\hline & 2-MNAP & 0.87 & 0.92 & 0.858 & 0.733 & 0.792 & 0.757 & 0.8625 & 12.712 & 0.8217 \\
\hline & $\Sigma 2$-ring PAHs & 3.203 & 2.872 & 2.586 & 3.149 & 2.436 & 2.282 & 2.5875 & 16.246 & 2.465 \\
\hline \multirow{6}{*}{3 -ring } & $\mathrm{ACY}$ & 7.345 & 3.22 & 12.383 & 0.935 & 3.954 & 7.61 & 1.1025 & 3.98 & 7.9467 \\
\hline & ACE & 0.87 & 0.92 & 0.858 & 4.135 & 0.792 & 0.757 & 0.8625 & 11.964 & 0.8217 \\
\hline & FLU & 11.5 & 31.746 & 14.167 & 9.338 & 7.474 & 14.645 & 0.1 & 8.95 & 25.217 \\
\hline & ANT & 17.378 & 13.566 & 38.483 & 14.428 & 12.91 & 10.122 & 31.9075 & 9.716 & 7.4233 \\
\hline & PHE & 22.638 & 4.036 & 7.9117 & 11.648 & 2.822 & 6.9683 & 5.44 & 18.238 & 10.573 \\
\hline & $\Sigma 3$-ring PAHs & 59.731 & 53.488 & 73.802 & 40.484 & 27.952 & 40.102 & 39.4125 & 52.848 & 51.981 \\
\hline \multirow{5}{*}{ 4-ring } & FLT $^{\mathrm{b}}$ & 18.523 & 16.984 & 10.438 & 7.808 & 10.534 & 9.495 & 16.5975 & 21.092 & 17.53 \\
\hline & $\mathrm{PYR}^{\mathrm{b}}$ & 15.728 & 18.054 & 21.427 & 18.483 & 2.758 & 7.68 & 3.9575 & 8.648 & 12.983 \\
\hline & $\mathrm{BAA}^{\mathrm{a}, \mathrm{b}}$ & 13.185 & 55.592 & 25.503 & 57.433 & 51.026 & 44.97 & 13.08 & 43.33 & 2.615 \\
\hline & $\mathrm{CRY}^{\mathrm{b}}$ & 8.65 & 13.672 & 18.407 & 19.403 & 4.594 & 16.128 & 23.4725 & 0.082 & 11.32 \\
\hline & $\Sigma 4$-ring PAHs & 56.086 & 104.302 & 75.775 & 103.127 & 68.912 & 78.273 & 57.1075 & 73.152 & 44.448 \\
\hline \multirow{5}{*}{ 5-ring } & $\mathrm{BBF}^{\mathrm{a}, \mathrm{b}}$ & 9.115 & 33.684 & 17.34 & 19.238 & 20.308 & 5.668 & 3.8175 & 42.078 & 14.523 \\
\hline & BKF & 0.083 & 0.088 & 0.08 & 0.07 & 0.074 & 0.0717 & 0.0825 & 0.092 & 0.0783 \\
\hline & $\mathrm{BAP}^{\mathrm{a}, \mathrm{b}}$ & 0.113 & 0.116 & 0.11 & 0.093 & 0.1 & 0.097 & 0.11 & 0.122 & 0.1033 \\
\hline & $\mathrm{DBA}^{\mathrm{a}}$ & 0.145 & 0.154 & 0.143 & 0.12 & 0.132 & 0.125 & 0.1425 & 0.158 & 0.135 \\
\hline & $\Sigma 5$-ring PAHs & 9.456 & 34.042 & 17.673 & 19.521 & 20.614 & 5.9617 & 4.1525 & 42.45 & 14.839 \\
\hline \multirow{6}{*}{ 6-ring } & $\mathrm{BGP}^{\mathrm{b}}$ & 0.04 & 0.04 & 0.038 & 0.03 & 0.03 & 0.03 & 0.0375 & 0.038 & 0.035 \\
\hline & $\mathrm{IND}^{\mathrm{a}, \mathrm{b}}$ & 0.208 & 0.214 & 0.207 & 0.173 & 0.19 & 0.18 & 0.205 & 0.22 & 0.195 \\
\hline & 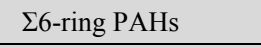 & 0.248 & 0.254 & 0.245 & 0.203 & 0.22 & 0.21 & 0.2425 & 0.258 & 0.23 \\
\hline & $\Sigma$ Total-PAHs & 128.72 & 195.2 & 170.08 & 166.478 & 120.134 & 126.83 & 103.5025 & 184.95 & 108.75 \\
\hline & Total Carcinogenic & 22.77 & 89.76 & 43.30 & 77.06 & 71.76 & 51.04 & 17.36 & 85.91 & 17.57 \\
\hline & CPAH (combustible & 65.35 & 138.14 & 93.26 & 122.49 & 89.35 & 84.07 & 61.07 & 115.39 & 59.11 \\
\hline
\end{tabular}

NAP: Naphthalene, 1-MNAP-2: 1-MethylNaphthalene, 2-MNAP-2: 2-MethylNaphthalene, ACY-3: Acenaphthlyene, ACE-3: Acenaphthene, FLU-3: Fluorene, ANT-3: Anthracene, PHE-3: Phenanthrene, FLT-4: Fluoranthene, PYR-4: Pyrene, BAA-4: Benzo(a)anthracene, CRY-4: Chrysene, BBF-5: Benzo(b) fluouanthene, BKF-5: Benzo(k)fluouanthene, BAP-5: Benzo(a)pyrene, DBA-5: Dibenz(a,h)anthracene, BGP-6: Benzo(g,h,i) perylene, IND-6: Indino $(1,2,3)$ pyrene.

${ }^{a}$ Carcinogenic compounds. ${ }^{\mathrm{b}} \mathrm{CPAH}$.

TABLE III: THE RATIOS OF MEAN CONCENTRATIONS OF BAP/BGP, IND/BGP, BGP/IND, IND/(IND+BGP AND BAA/(BAA+CRY AT SAMPLING SITES

\begin{tabular}{|l|l|l|l|l|l|l|}
\hline $\begin{array}{l}\text { Dust } \\
\text { Fraction }\end{array}$ & Site & $\begin{array}{l}\text { BAP/ } \\
\text { BGP }\end{array}$ & $\begin{array}{l}\text { IND/ } \\
\text { BGP }\end{array}$ & $\begin{array}{l}\text { BGP/ } \\
\text { IND }\end{array}$ & $\begin{array}{l}\text { IND/ } \\
\text { IND } \\
\text { +BGP }\end{array}$ & $\begin{array}{l}\text { BAA/ } \\
\text { BAA+ } \\
\text { CRY }\end{array}$ \\
\hline TSP & $\begin{array}{l}\text { Al-Azi } \\
\text { zia }\end{array}$ & 2.83 & 5.20 & 0.192 & 0.84 & 0.6 \\
\hline & $\begin{array}{l}\text { Al-She } \\
\text { bakah }\end{array}$ & 2.90 & 5.35 & 0.187 & 0.84 & 0.8 \\
\hline PM10 & $\begin{array}{l}\text { Mina } \\
\text { zia }\end{array}$ & 2.89 & 5.45 & 0.184 & 0.84 & 0.6 \\
\hline & $\begin{array}{l}\text { Al-She } \\
\text { bakah }\end{array}$ & 3.33 & 6.33 & 0.158 & 0.86 & 0.9 \\
\hline & Mina & 3.23 & 6.00 & 0.167 & 0.86 & 0.7 \\
\hline PM2.5 & $\begin{array}{l}\text { Al-Azi } \\
\text { zia }\end{array}$ & 2.93 & 5.47 & 0.183 & 0.85 & 0.4 \\
\hline & $\begin{array}{l}\text { Al-She } \\
\text { bakah }\end{array}$ & 3.21 & 5.79 & 0.173 & 0.85 & 1.0 \\
\hline & Mina & 2.95 & 5.57 & 0.179 & 0.85 & 0.2 \\
\hline
\end{tabular}

TABLE IV: CPAH, $\Sigma$ PAH AND CPAH/ $/$ PAH RATIOS AT THE SAMPLING

\begin{tabular}{|c|c|c|c|c|}
\hline \multicolumn{5}{|c|}{ SITES } \\
\hline & PM/ Site & CPAH & $\Sigma$ PAHs & CPAH/LPAHs \\
\hline \multirow{3}{*}{ TSP } & Al-Azizia & 65.35 & 128.72 & 0.51 \\
\hline & Al-Shebakah & 138.14 & 195.2 & 0.71 \\
\hline & Mina & 93.26 & 170.08 & 0.55 \\
\hline \multirow{3}{*}{$\mathrm{PM}_{10}$} & Al-Azizia & 122.49 & 166.48 & 0.74 \\
\hline & Al-Shebakah & 89.35 & 120.134 & 0.74 \\
\hline & Mina & 84.07 & 126.83 & 0.66 \\
\hline \multirow{3}{*}{$\mathrm{PM}_{2.5}$} & Al-Azizia & 61.07 & 103.502 & 0.59 \\
\hline & Al-Shebakah & 115.39 & 184.95 & 0.62 \\
\hline & Mina & 59.11 & 108.75 & 0.54 \\
\hline
\end{tabular}

CPAH , combustible PAHs species

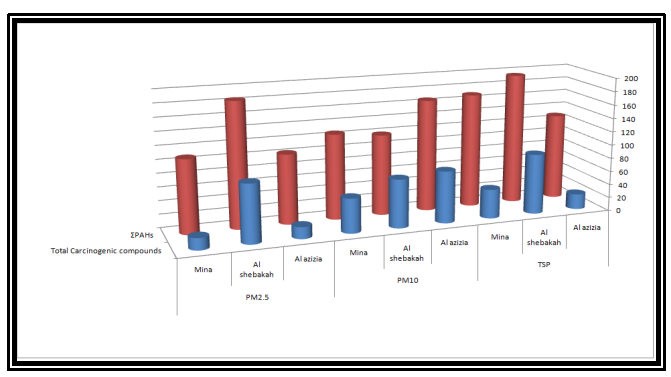

Fig. 4. Total concentrations of PAH and carcinogenic compounds at different sampling sites in Makkah city. 


\section{CONCLUSION}

The present study confirms the contribution of vehicular traffic, industrial emissions and the incomplete combustion of open waste burning to atmospheric PAHs. The pollution of PAHs in Makkah city should be managed on controlling traffic exhausts. Further work is needed to develop this preliminary investigation, including more measurements in other locations. Typical environment in Saudi Arabia of high temperature and relative humidity, coupled with abundant sunshine, may result in different chemistry of PAHs from that of other geographical regions.

\section{REFERENCES}

[1] W. L. Xue and D. Warshawsky, "Metabolic activation of polycyclic and heterocyclic aromatic hydrocarbons and DNA damage: a review," Toxicology and Applied Pharmacology, vol. 206, pp. 73-93, 2005.

[2] F. Esen, Y. Tasdemir, and N. Vardar, "Atmospheric concentrations of $\mathrm{PAHs}$, their possible sources and gasto- particle partitioning at a residential site of Bursa, Turkey," Atmospheric Research, vol. 88, pp. 243-255, 2008.

[3] B. Zielinska, J. Sagebiel, W. P. Arnott, C. F. Rogers, K. E. Kelly, D. A. Wagner et al., "Phase and size distribution of polycyclic aromatic hydrocarbons in diesel and gasoline vehicle emissions," Environmental Science and Technology, vol. 38, pp. 2557-2567, 2004.

[4] S. K. Hassan, "Atmospheric polycyclic aromatic hydrocarbons and some heavy metals in suspended particulate matter in urban, industrial and residential areas in Greater Cairo," Ph.D. Thesis, Cairo University, Egypt. 2006.

[5] M. I. Khoder, "Sources and distribution of polycyclic aromatic hydrocarbons in wet deposition in urban and suburban areas of Giza, Egypt," Central European Journal of Occupational and Environmental Medicine, vol. 12, pp. 279-296, 2006.

[6] M. A. Hassanien and N. M. abd Abdel-Latif, "Polycyclic aromatic hydrocarbons in road dust over Greater Cairo, Egypt," Journal of Hazardous Materials, vol. 151, pp. 247-254, 2008.

[7] S. K. Hassan and M. I. Khoder, "Gas-particle concentration, distribution, and health risk assessment of polycyclic aromatic hydrocarbons at a traffic area of Giza, Egypt," Environ. Monit. Assess, vol. 184, no. 6, pp. $3593-3612,2011$.

[8] National Academy of Science (NAS), Particulate polycyclic organic matter, National Academy Press: Washington, D.C, 1973.

[9] H. Yamasaki, K. Kuwata, and H. Miyamoto, "Effects of Ambient Temperature on Aspects of Airborne Polycyclic Aromatic Hydrocarbons," Environ. Sci. Technol., vol. 16, no. 4, pp. 189 - 194, 1982.
[10] K. E. Gustafson and R. M. Dickhut, "Particle/Gas concentrations and distribution of PAHs in the atmosphere of southern Chesapeake Bay," Environ. Sci. Technol, vol. 31, pp. 140- 7, 1997.

[11] L. Zhu, H. Lu, S. Chen, and T. Amagai, "Pollution level, phase distribution and source analysis of polycyclic aromatic hydrocarbons in residential air in Hangzhou, China," J. Hazard. Mat, vol. 162, no. 2-3, pp. $1165-1170,2008$.

[12] S. O. Baek, "Significance and behavior of polycyclic aromatic hydrocarbons in urban ambient air," PhD Thesis, Imperial College of Science and Technology, University of London, 1988.

[13] M. Zheng and M. Fang, "Correlations between Organic and Inorganic Species in Atmospheric Aerosols," Environ. Sci. Technol., vol. 34, pp. 2721-2726, 2000.

[14] H. Sharma, V. K. Jain, and Z. H. Khan, "Characterization and source identification of polycyclic aromatic hydrocarbons (PAHs) in the urban environment of Delhi," Chemosphere, vol. 66, pp. 302-310, 2007.

[15] G. C. Fang, C. N. Chang, Y. S. Wu, P. P. Fu, I. L. Yang, and M. H. Chen, "Characterization, identification of ambient air and road dust polycyclic aromatic hydrocarbons in Central Taiwan," Sci. Total Environ, vol. 327, pp. 135-146, 2004.

[16] D. W. M. Sin, Y. C. Wong, Y. Y. Choi, C. H. Lam, and P. K. K. Louie, "Distribution of polycyclic aromatic hydrocarbons in the atmosphere of Hong Kong," Journal of Environmental Monitoring, vol. 5, pp. 989-996, 2003.

[17] H. H. Yang, S. O. Lai, L. T. Hsieh, H. J. Hsueh, and T. W. Chi, "Profiles of PAH emission from steel and iron industries," Chemosphere, vol. 48, pp. 1061-1073, 2002.

[18] International Agency of Research on Cancer (IARC), "Monograph on evolution of the Carcinogenic Risk of Chemicals to Human, Polynuclear Aromatic mounds, Art 1," Chemical, Environmental and Experimental Data, Lyon, France, vol. 32, pp. 125-140. 1983.

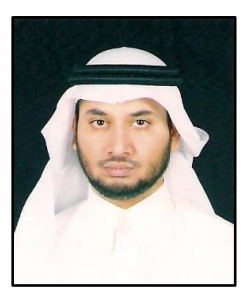

Turki M. Habeebullah was born on 31 Jan. 1976 in Makkah, Saudi Arabia. His got his $\mathrm{PhD}$ in Air Pollution Meteorology (2006-2010), University of East Anglia, Norwich, United Kingdom. He focuses on Meteorology, Biometeorology, Microclimate, Hydrology, Air pollution and its impact on health, Environmental sampling \& analysis, Heavy metals and organic compounds, Emission inventories, Dispersion of air pollution and Risk assessment. He is an assistant professor at the Custodian of the Two Holy Mosques Institute for Hajj and Umrah Research, Umm Al-Qura University, Makkah, Kingdom of Saudi Arabia. The author has done many publications. He did lots of research and projects on the field of air pollution and its impact on health

Dr. Habeebullah has been given Employee Award ideal in 1999, and also, excellence award by the custodian of the two holy mosques institute of hajj research in 2004. 